\title{
Surgery today: How to keep the golden mean within our academy?
}

\author{
F. M. Riegler
}

Published online: 28 October 2014

(C) Springer-Verlag Wien 2014

\section{Dear Reader,}

It would be great if you could find time to read these considerations, which are at least in part suggested to be within your focus of interest. If not, feel free to skip it and enjoy reading the papers of European Surgery's present issue. Maybe you will find the mood, space, and time to return to it later.

Going in line with the current developments regarding the management, the personal and ideological adjustment within the Central European Surgical Academy, it may be allowed to question the reason for these essential changes. Modern surgery became minimally invasive, has to keep up with "novel" life style diseases (obesity, diabetes, cancer, etc.), and needs to incorporate an adequate structural and logistic basis including teaching, education (common trunk, specialization), and patient care to adequately meet the requirements of our time. In addition, we have to consider the personality, mind set, and motivation of the employees doing the job. Taken down to the common ground this may translate into the manifestation of four major and prominent economydriven archaic human qualities (archaiconomy; Table 1). These qualities are streaming out, over and through the human mankind following transient, permanent, pulsatile, fast, slow, or immediate velocity speed waves of appearances and vanish to explicitly and fundamentally cover and hide the essence of the "once upon a time theme": What lies beyond the nature of perception?

Whenever, dear reader, you may attest and diagnose any misbehaving, dislike, or any probability of statistically assessable flow of mood abnormality and disagreement within yourself or within the so-called spectrum

F. M. Riegler ( $\square)$

Reflux Medical,

Mariannengasse 10/9,

1090 Vienna, Austria

e-mail: martin.riegler@refluxmedical.com of YOUR complex meaningful outer world, the center of which you are, then this very perception can always be drawn back to one of the four archaic qualities. As shown and depicted in Table 1, these four major archaic MUST HAVE qualities or drives of the human nature list: reproduction, hunger, killing, and entertainment. This translates, and this is also shown in Table 1, into the satisfaction of these archaic needs and drives in the form of prostitution, nutrition and life style, warfare and entertainment industries (world wide web, clothing, car, home, technology, science, etc. globalization industries).

Basically and conceptually it all represents the same: necessary forms to bridge the boredom of our existence. Energy is, manifestation passes, action compensates, nature flows. Without entertainment we would be forced to "suffer" pure being. If your fingers stop to know how to bridge time, you start to smoke, drink, eat, use joints, and perception modulating drugs (Lucy in the sky with diamonds). Based on the so-called cultural oscillations (shine on you crazy diamond) and mood of a given civilization (money), the manifestation of these archaic qualities of the human nature are both nourished and satisfied within a broad and wide spectrum of facilities and work out places to cover the dark side of the moon. Needs drive the market, nourish the economy, wall the street. The "ness" disciplines offer fitness, wellness, regardless. Therefore, temple, church, super market, foot-/baseball/soccer stadium, theater (Fig. 1), concert hall, opera house, museum, amusement wonderland, and academy all serve to satisfy the same need: they serve to justify the expression and translation of these archaic energies into a less destroying form. Boredom kills. Modern myths teach how the red bull strikes the planet to coke down the overseas Isis and Osiris legacy into pieces of a novel form of worship: modern metal tin germ buds will not form roots to the ground, instead humans start to eat what they somehow feel to have lost: healing earth for the taste of testimony, the last shine shadow shrine 
Table 1 Economic translations of archaic human qualities for the bridging of boredom: instinct drives economy, manifests nature (archaiconomy ${ }^{\text {a }}$ )

\begin{tabular}{l|l|}
\hline Archaic quality & \multicolumn{1}{|c|}{ Translation/industry } \\
\hline Reproduction & Sex \\
\hline Hunger & Food and beverage industry \\
\hline Killing & Technology, science, warfare \\
\hline Entertainment & Life style/health care \\
\hline $\begin{array}{l}\text { The justification of the translation of archaic qualities of the Homo sapiens } \\
\text { stays outbalanced as "morality" and serves as the basis for the politics } \\
\text { (ideology), the explanation of materialism } \\
\text { aArchaiconomy = highly profitable economy aimed to satisfy the archaic } \\
\text { qualities of the human nature. }\end{array}$
\end{tabular}

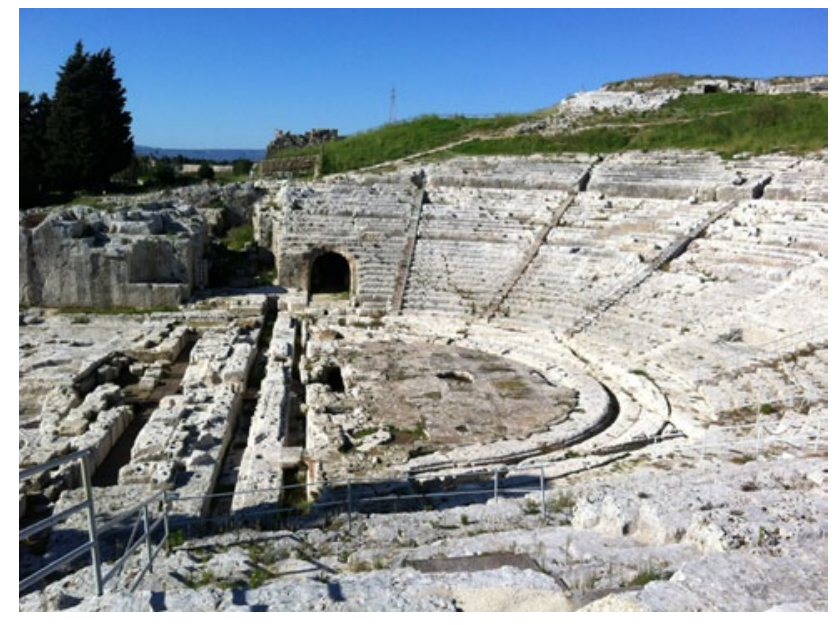

Fig. 1 Image obtained at the ancient Greek theater of Siracusa, Sicily, Italy, Europe, where man used to stage the essence of his being in order to bridge the boredom of his existence, as described in the text

within the chamber of ready roots upon legacy: river runs without Heraclitus belly bridges to coast, mantle the Parmenides sea well water drop temper taste tick tangles the Anaximander ocean, gently wipes the waves into the Platon nutshell nature glory big biter board bubble builder in rim ram James nobody Joyce arms as previously described by here comes earth $(p<0.05)$.

If well embedded into some grade of open-minded education and economic security the energies are balanced out in the form of "culture", way of life, including technical achievements in the form of multiple borrowed possessions (houses, castles, islands, cars, airplanes, jewelry, ball point pen, knife, chewing gum, etc.). In the absence of education in tolerance and passion, these energies are abruptly released as waves and storms of aggression (main dish, dessert storm), brutality, and wars, as shown in the political developments in the past, now and in the future.

Thinking cannot eradicate and replace the satisfaction of reality-termed qualities, but it may help to foster slow motion manifestations of the nature, kiss instead of bite, caress instead of kill. Well taken, you identify the major factor spoken about is time. Time goes, passes, hides, and uncovers, allocates things to come into our perception and vanish out of our perception. Thus, modern man continues to adhere to the surface and "developed" to become a cell phone and iPad-guided application of the world wide web and serves the satisfaction of the need greed power games drives of the various forms of archaic quality translators, i.e. the industries (food, entertainment, music, art, cloths, weapons, cars, science, hardware, software, playstations, etc.). Technology is the calculative interpretation of nature. The wall street win-win notion translates into the digest-it-all for their benefit. The gullet back bills the bullet. But who are the winners? Earth crust displacement does not care about stock market exchange developments at Wall Street, political insecurity in the East ( \pm regular bombings and extinction of thousands of lives) and antipeople warfare. It simply rocks the land and pushes it out of our vision. Thus resides the legacy of the lost civilization packed under $150 \mathrm{~m}$ of sea water and $4000 \mathrm{~m}$ of ice, storm, and snow.

Morality usually serves to mask the true power game intentions. The same energy released over a longer period of time nourishes millions of people; extruded in the form of a brief, short, brutal tsunami, it kills and destroys with statistically significant power $(p<0.001)$. You like statistics because the majority of academics cannot stand perceptions which are not measurable, comparable, and brought into a form for collection and calculation. But dear reader, have you ever asked yourself if there may be something beyond the level of calculation, presentation, and statistical manipulation? What fixes the anastomosis? Is it your hand sewn suture? Or may there be something else beyond? What makes the heart beat? Pure ion channel work out? Or may there be an allocator behind it all? Remains to be questioned if this approach may offer a different explanation of our academy?

May it be that what we suggest to be a wonderful, beautiful, productive academy, in fact serves the justification and work out of archaic qualities including envy, greed, and hate, gathering around an idea which is then physically and intellectually misused and mistaken as gods, morals, philosophy, concepts, science, and excellence? Did we lose the sensitivity for the essence? What sounds through the masks of morality, dignity, and personality? May it be that the major and only ground for our existence has withdrawn itself from our vision, perception and reasoning, leaving us lonely and lost within our network of power games, forced to overcome this lack with continuous, permanent entertainment? What happened to the nature of man? No time for a pause! Will the spiders be embedded within their own nets and drop out and down to become the soil for a manifest google sound? Face the book, iPad the mad. May it be that we live to await, that the crazy gnome of the new day will step out of the mass of academics and shout out loud: "I sense a future age, where the twilight of our academy will be perceived and remembered as a good old history... The gnome already identifies the well textured and colored beaches, which are presently covered by the waters of nonpolarized waves? Are these strands of lands out 
there to await and be ready for the major beam of light to bring them into our attention? Or will the light continue to serve to make them shine like a crazy diamond? Who needs the dark side of the broken moon? Are we ready for the gnome? Are we ready for a real thinker, who reveals the real secret of our nature and translates it into a stream of mood which fosters medicine, surgery, to become art?

May it be that it all relies to a certain unknown, global, world-wide power lobby (the global office), controlling and manipulating the entire spectrum of needs and requirements our modern civilization, ranging from food, life style, nutrition, entertainment, religion, science to warfare? May it be that it has been like that since ever, since the once upon a time has been spoken out by the successors of the lost civilization and forgotten, and that politics only serve to justify the satisfaction of these archaic needs? Instincts are and hide the essence. Are there still individuals within our academy, who are open minded to purely think without masking power game intentions?

May it be that the unidentifiable invisible power has already been brilliantly mirrored by the ancient Egyptians in the form of the sun disc spreading out the allcontrolling and manipulating arms leaving humans in blindness, dependence and insecurity (Fig. 2)? Even the king, the pharaoh, with his family, wife, kids, temples,

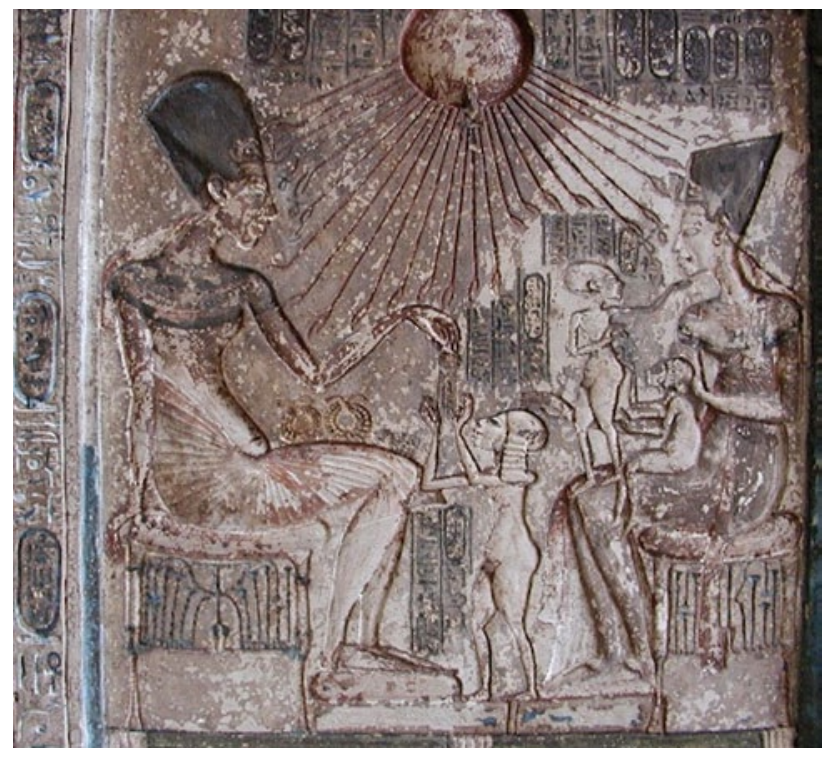

Fig. 2 The ancient Egyptian pharaoh Akhenaten, his wife Nefertiti and children under the life spending energy of the sun god Aten (around 1340 B.C., Amarna period, eighteenth dynasty). The image mirrors the idea of the author, that the sun disk represents the unknown, misty, hidden global power, which is indicated by the arms, conducts remote control of the humans to induce, satisfy and define their life and existence. At present the sun disk would represent the world power lobby creating immense economic profit by serving the satisfaction of the needs raised by the archaic human qualities (= archaiconomy), as depicted in Table 1 and described in the text. Image obtained from the Egyptian museum, Cairo (Nr. JE 44865) cities, horses, soldiers, rivers, and gods left in isolation? May it be that due to the fact that man is not able to stand the perception of this essential truth (= thinking) for longer than a short momentum, the Akhenaten business had been given up and had to sink into the darkness of oblivion? May it be that since then we have to repeat the same, continuously, replacing and hiding the essence by gods, ideologies, philosophies, and opinions? May this be the pure reason for the present negatively tuned "perceptions" in our academy? Remains to be questioned the mindset of the employees.

Around his throne the academic leader gathers very good physicians, well-trained surgeons and great experts with brilliant performance. A good and effective leader aims to elegantly outbalance and positively orchestrate the wide and broad personality spectrum of the employees of a given institution including different types of characters (weak-strong; individualistic-opportunistic), attitudes (greed-humility), qualities (authority-coward) and natures with their individual professional perspectives, i.e. to be prepared to take the lead in another institution or to offer a great job in the second or third row of the team.

Taken together, it seems justifiable to assume that the academy should try a mindset including the entire spectrum from purely thinking the being to the perfect manipulation and calculation of the things (matter of mathematics) of the so-called materialistic physical world (Fig. 3). It seems that we need a professor-director showing us the outbalanced path adequately orchestrating in between the extremes of the spectrum (Fig. 3).

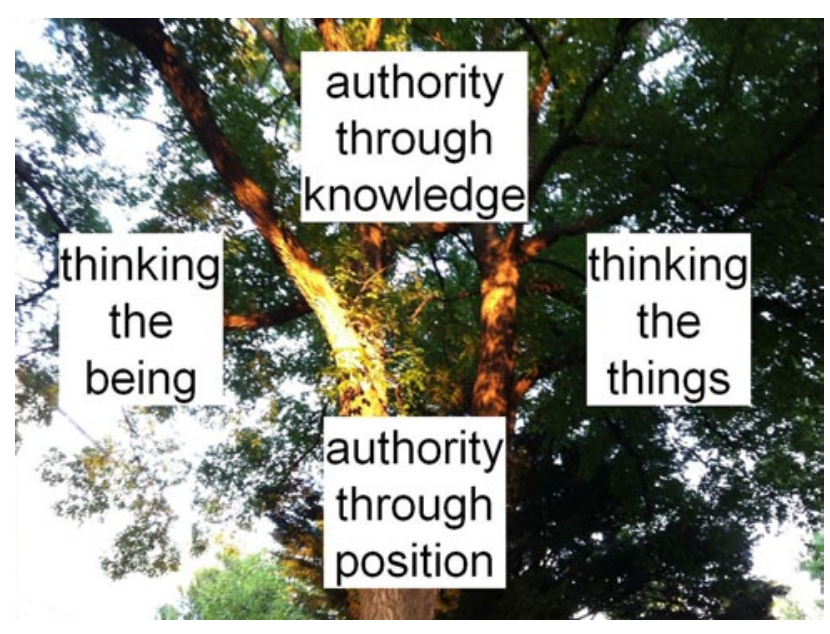

Fig. 3 Mindset spectrum of the academy. Conceptually two types of spectra are to be fused and well taken for a leader within the academic arena: from thinking the being to thinking, handling, calculating, power game striking, and safekeeping solely things (i.e. exclude thinking the being), and from taking the lead through the authority of knowledge down to the power given and only justified by the lead position. As outlined in the text, a "good" leader excellently outbalances the spectra to keep the golden mean for the benefit of the patients, employees and the scientific aims of the academic institution. May such a personality take the lead and prosper our academy 
Thus, let us pave the way to give the academy a perfect shine of excellence. Is there anyone out there to do so, today? Otherwise we will have to await the outcome of the idiopathic state of affairs, far off from sensing the essence ground. May it be that our language has lost the words to question beyond perception? May we unhide a forgotten legacy allowing us to put into words what simply is, beyond $p$-values, Kaplan-Meier curves and any calculation? This would be the perfect moment to "renew" the mindset spectrum for our academy. May the recent and current changes within the managing personnel of our academies foster the release of an open-minded authority to support a positive development for our institutions and to adequately meet the requirements of the patients and the employees. Would anybody have the personality to meet the requirements: be without shine, foster without applause? So far they staged Hartman's return at the Vienna Royal Theatre: le roi est mort, vive le roi. The old king's soul has been immediately waved out of his palace (and may return through the doors of another king's palace?). Will the new king's soul face the same glory, when it will be time for him to go? And the ancient king became legacy and went to the stars. All happened at the same time: may this concurrence be due to chance or does it tell us more? Only one thing remains the same: the crown does not die. It would be great if such a vision came into being: It is all about life quality and the stream of mood. What's up? Show me your data. Great job. Are numbers the only way to esteem and define success? Do not stop to ask yourself why there is being and not simply nothing at all? Enjoy fall for (Johnny) winter without 20,000 years of ice.

\section{Acknowledgments}

The author thanks the Egyptologist Mrs. Anja Wutte MA, Vienna, for her outstanding, professional and highly stimulating and motivated support regarding an additional interpretation of the Akhenaten sun disc symbolism depicted in Fig. 2. The editorial is dedicated to those, who do not stop to think the essence and do not give up to trust in our academy and continue to stand behind all intellectual, logistic, productive, and economic activities fostering a positive outcome of the current crisis and imbalance of our academy.

\section{Conflict of interest}

The author declares that there is no conflict of interest. 